\title{
John Enos
}

All governments of the developing countries intervene in their economies. In the past, economists have done little more than list interventions, commending those that confirm to their own ideological precepts and condemning those that do not. Recently research has been undertaken with the aim of filling this void and providing systematic studies of government behaviour and its consequences. The following article reports one such attempt.

The research focused on South Korea (Korea hereafter) and was concerned with the choice and absorption of modern industrial technology imported from abroad [Enos and Park forthcoming]. To neither the Korean economists and engineers engaged in the research, nor the one foreign economist, did it seem remarkable that the Korean Government took part in the process of adoption of foreign techniques; but to the latter, acquainted with the participation of governments of several other developing countries, what did seem remarkable was that the Korean Government took part throughout the process, and to good effect.

Continuous and competent intervention by the Korean Government in major economic activities appears to be the rule rather than the exception. Both those inside government and those in the private sector accept that the national interest should be fully represented and that its representation should require the government's active participation. To use a theatrical idiom, the government is always to be on stage, filling all the roles for which its talents equip it. Dramatically, it is the ever-visible protagonist.

In this article three points will be made: first, that the adoption of sophisticated techniques requires the continued attention of one economic agent over a substantial length of time; second, that in Korea the government has been that agent; and third, that our understanding of the effects of government intervention in the economic affairs of developing countries is quite inadequate. In illustrating these points one case will be drawn upon repeatedly, that of the adoption of imported techniques in the petrochemical industry.

\section{History of Petrochemical Development}

The chronology of the petrochemical industry in Korea begins in the early 1960s when the government conceived of an integrated petrochemical complex, supplied with ethylene, the chief raw material, from a plant located at a planned petroleum refinery. The petroleum refinery was completed in 1967, and the ethylene cracker was included in the Second Five Year Plan, 1967-71. Planning for the petrochemical complex proceeded concurrently, with separate studies of the types of petrochemicals to be manufactured, their scales of operation, alternative industrial structures and organisations of firms, and availability of (foreign) techniques. Coordinating the studies was the government's Economic Planning Board; the studies themselves were carried out by various ministries and state enterprises, by the US aid agency and by foreign consultants.

Having made certain policy decisions - that petrochemicals should be produced employing the current state of the art in the developed countries, by means of joint ventures with foreign firms, one product to each firm - the Korean Government in 1968 initiated negotiations with all foreign firms, in all developed countries, capable of supplying the technology. Many suppliers were approached; 13 and nine for polyethylene and vinyl chloride monomer (VCM) respectively, and similar numbers for the other petrochemicals. The government's vehicle in the negotiations was the Chungju Fertiliser Company (subsequently the Korea General Chemical Corporation), which had been established with US government aid and which then operated two plants, constructed eight and six years previously. Chungju was chosen to represent Korea because it employed the nation's largest group of chemical engineers. whose experience was necessary in evaluating the technical and economic terms of any foreign offer. 
With the exception of those for one product, caprolactum (the raw material for nylon), the negotiations between the Korean Government and the foreign suppliers proceeded in a similar manner, with the government imposing increasingly stringent conditions until all but one of the foreign contenders had dropped out. With the remaining foreign firm the government signed a contract for the provision of the technology; the arranging of finance; the training of Koreans as technicians, engineers and managers; the supervision of design, construction and initial production in the petrochemical plant; and the organisation and responsibilities of the joint venture. For caprolactum, the government was not able to negotiate what it felt to be satisfactory terms for a joint venture, so it decided to license a foreign design and itself undertake all the other activities - financing, training, production and management.

After the contracts had been signed in 1968 and 1969 the chief responsibility for their performance devolved from the Chungju Fertiliser Company to the joint ventures (called Korea Pacific Chemicals in the case of the firm producing polyethylene and VCM) and to the Ministry of Commerce and Industry. Although the staffs of these two entities were of different status, those of the former being employees of a semi-public firm and of the latter being civil servants, their superiors were drawn from the same elite, namely the military officers and technocrats surrounding the President of the Republic. The top administrative officer of Korea Pacific Chemical Corporation, for example, had previously been a general in the Korean army.

By the time the Third Five Year Plan 1972-76 was published, work on the petrochemical plants was well under way. The signing of the contracts with the foreign suppliers had been followed by the designing of the plants, the training of the Korean engineers, the ordering of the capital equipment, the preparation of the sites, the construction of foundations, buildings, workshops, laboratories, and housing, and the installation of the equipment. Approximately 10 years after their conception, and five years after the completion of negotiations, the petrochemical plants began operation.

\section{Persistent Intervention}

But just as the Korean government's concern did not end with access to the technology so it did not cease with the onset of production. The Heavy and Chemicals Industries Ministry, created to administer those activities laid out in the Third Five Year Plan, oversaw the operation of the joint ventures, facilitating the delivery of raw materials and spare parts, assigning prices and markets for the output, and assuring fulfilment of the conditions of the contracts, particularly with regard to the utilisation of capacity. The Ministry also intervened in cases of emergency, for example when there was an explosion at one of the plants. Intervention then took the form of expediting the procurement of replacements for the equipment destroyed (supplied domestically rather than, as originally, from abroad) and putting pressure on the joint venture swiftly to resume production.

Apart from its regular activity of overseeing the operations of the petrochemical manufacturers, the Korean Government has subsequently made three major interventions. The first of these was after steady and profitable production of petrochemicals had been secured, when the government floated its half share of the joint ventures on the Korean share market, thereby transferring ownership to its private citizens and raising some of the capital to finance the next round of petrochemical investments.

The second intervention took place in the establishment of the second petrochemical complex, at Yeocheon in the south-west. There, six years after production began at Ulsan, operations began on a larger scale; before this the Korean Government had once again negotiated contracts with foreign suppliers of technology, in the main those with whom it had come to agreement in the course of the first set of negotiations.

The third major government intervention occurred in 1982 when one of the foreign suppliers, by then engaged in two joint ventures, one each at Ulsan and Yeocheon, became dissatisfied with its role and with the benefits it was receiving. After negotiations, a court suit, and still more negotiations the foreign participant, Dow Chemical Company of the USA, agreed to sell its share of the assets of the companies to the Koreans, so that these enterprises became wholly national.

One observation that can be drawn from this history is that the government's influence has persisted. From the conception of a national petrochemical industry in the early 1960s, through the choice of suppliers of the sophisticated technology, the specification of the conditions under which the technology was to be provided, the construction and operation of plants, and the expansion of capacity, to the change of ownership in 1982, the Korean Government has been continually on the scene. Throughout the whole 20 years of its existence the industry has received the constant attention of the government. To be sure, administrations have changed, responsibilities have been shifted from one department or one ministry to another, personnel have retired or moved on, but the government has stayed, omnipresent. No other actor 


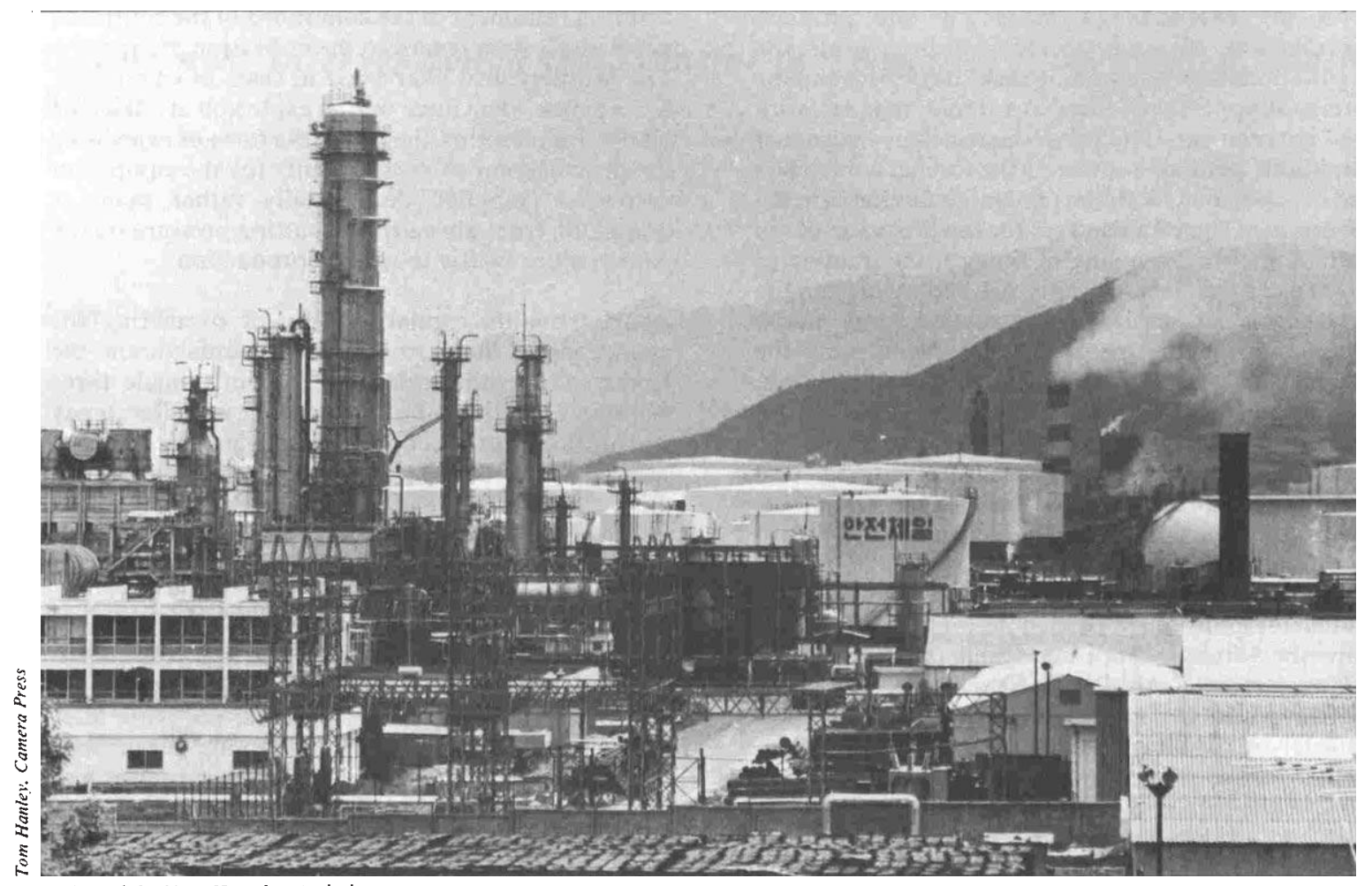

A view of the Nam Hae chemical plant at Yeosu.

- foreign financiers, capital goods suppliers, producing firms, providers of the technology - has been always on the stage. The financiers enter early and soon leave, the capital goods manufacturers participate from time to time, the producing firms come into being only after their legal and operating environments have been established, and the technology suppliers may depart some time afterwards: the Korean Government remains on hand.

'Remaining on hand' describes adequately the presence of the Korean Government throughout the process of adopting technology, but misses the other characteristic that it has displayed, namely determination. The government has always been to be on the spot, intervening whenever this seemed to be in the public interest. Both those who intervened and those in whose affairs intervention took place appeared to accept as legitimate the government's continual presence. Whether it was formulating and implementing policy, monitoring performance, rewarding success or punishing failure, the Korean Government was felt to be fulfilling its duty to the nation.

The word which best captures this overt acceptance of the constant playing of the major role in the process of industrialisation is persistence. As our research has shown, the Korean Government has persisted in planning, in setting policy, in negotiating, in organising, in overseeing, and in intervening, at every stage during the adoption of foreign technologies; the research of some others whose scope has been broader than ours indicates that the Korean Government has also persisted in planning, policy-making and implementation elsewhere in the economy [Ho 1981; Jones and SaKong 1980; Wade 1982].

\section{The National Interest}

Persistence is one of three attributes which together account for the relative success of the Korean government's interventions in the economy; the other two are patriotism and primacy. To the (nonJapanese) foreigner the Koreans, old and young, rich and poor, rural and urban, privately employed and civil servants, are remarkable in their awareness of a national interest and in using this national interest as a guide for their own behaviour. In the material sphere the national interest is furthered by the construction of a modern industrial economy, involving the adoption of the best of foreign technologies and institutions, and employing all the talents and industry of its citizens. In outline there is nothing unusual about this 
statement: one encounters paraphrases in almost every developing country. What distinguishes Korea from most of the others is that the statement is not rhetoric; it is heartfelt, and it motivates actions. Koreans, government officials included, will work harder, will subordinate themselves, will make sacrifices, to attain the national good.

Translated into economic attitudes, patriotism leads to the acceptance of production targets as reasonable outcomes, of government institutions as legitimate instruments, and of commands directed towards the attainment of targets and issued by public officials as justifiable directives. Leaders are quick to order, civil servants are quick to implement and producers are quick to obey when the performance of the economy is at stake.

Translated into economic decisions patriotism leads to choices that are recognised to be in the public interest, against alternatives that bring greater private rewards to the decision-makers. Development economists in other countries are accustomed to seeing alternatives chosen which bring the greatest tribute to the country's leaders and their subordinates, which yield the greatest amounts of scarce foreign exchange to the capitalists, which cause the fewest disturbances in the existing economic and political order, ie, alternatives in which the personal preferences of the decision-makers override the national interest. No such choices were observed in the course of our research in Korea; in no case where there was an obvious conflict between personal and national interest had the former triumphed.

\section{The Primacy of Government}

If by patriotism in government we mean the subordination of the politician's and the civil servant's private interests to the acknowledged objectives of the nation at large, by primacy we mean the independence of the same individuals from pressures which would deflect them from attaining these objectives. In Korea, unlike most other developing countries, one does not find extra-governmental forces - wealthy families, ethnic or tribal or regional groups, multinational firms, etc - controlling government. No particular interest need always be considered in the determination and implementation of public policy. No civil servant need temper his recommendation or command because of its likely effect on a favoured party. Issues are more clearcut, decisions and actions are swifter, where government is supreme.

Maintaining primacy appears to be a constant concern of the Korean Government, requiring vigilance and a willingness to cut down to size, dissolve or even destroy any other force that becomes excessive. Con- flicts may arise between the attainment of an economic target and the growth of power or wealth of the agent which produces the targeted goods; in such situations lower priority may be at tached to the economic than the political objective. The national interest may not suffer, however, if the extra-governmental force, strengthened by the accretion of power or wealth, would have been able subsequently to substitute its own objectives for those of the nation. Reducing the scope for the representation of private preferences may be in the public interest.

\section{Assessing the Impact of Public Intervention}

That the Korean Government has intervened in the economy is not in question; what is questionable is that the intervention has been useful. To prove that government action has benefited an economy is impossible, since one cannot tell how the economy would have performed had government not intervened. The counterfactual case cannot be appraised.

In the absence of controlled experiment one has to rely upon comparisons between actual performance, on the one hand, and typical or standard performance, on the other. Comparisons involving the entire economy are often made, comparisons from which Korea, with its high rate of growth of output and relatively even distribution of income, emerges successfully. Such comparisons are so general, however, that they do not enable one to distinguish between the effects of government actions and the effects of all other influential factors - in Korea's case the legacy of organisation and skills from the recent liberation from colonial status, the post- 1950 military and financial contributions from the USA, the constant challenge from North Korea and the discipline and diligence of the Korean people. Perhaps the most one can conclude from such macroeconomic comparisons is that efficient, incorruptable government dedicated to economic development is a necessary condition for success, a rather bland statement although one with some empirical support [eg Adelman and Morris 1967].

The particular contribution of government may be more visible when the comparisons involve microeconomic phenomena. Relevant government notices and actions can be more easily identified, and their consequences traced through. Or a specific microeconomic outcome can be focused on, and those government policies and actions which affected this outcome can be determined. Political and administrative scientists prefer the first of these approaches, economists the second, since they can then select outcomes expressed in quantitative terms.

In our research we selected three measurable outcomes of the process of ad opting technologies: one 
organisational, one output-centred. and one inputcentrid. which together secmud to give some indication of the degree of Korca's success.

The organisational measure was the percentage of Korcans in the total number of engineers engiged at each stage of the absorption of a ncw technique. The data for the two petrochemical techniques involved in the production of polycthylenc and VCM are given in the table below.

The data reveal that there were a sufficient number of engincers in Korea to fill the bulk of the operating posts. but not enough initially to carry out the more highly skilled jobs of design and procurement. Betwein the preparation for the first plant at Ulsan and the second at Yeocheon. however. some Koreans werc trained to carry out these functions too. In comparison with petrochemical operations in other developing countries the percentages in Table 1 are quitc favourable to Korea.

The output-centred measure was two dimensional, the first being the speed with which facilities were bronght to full-capacity operation and the second. the percentage by which design capacity was subsequently exceeded. Exceeding design capacity is of ten possible. for engineers tend to be conservative in their sizing of equipment. but the extra output is won only when those operating the equipment have come to know thoroughly its capabilities.

In the case of the two petrochemical plants at the Ulsan complex the rate of ollput rached design capacity in six months and 40 months for polycthylene and VCM respectively. By 1978. five years after initial operation, polyethylene output exceeded design capacity by 35 per cent, and VCM by three per cent. These also arc enviable figures by the stanctards of plants employing sophisticatted techniques in developing countries.
The input-cintred measurc of the sllccess in adopting imported techniques is also multidimonsional. since it attcmpts to determine the productivity of the various inputs. singly and collectively. in producing output. The productivities that could be measured in the case of petrochemicals were the separate ones of raw matcrial and energy. and the aggregatcd one of total factor productivity. (The productivity of fixcd capital increased in dirce proportion to the increase in output from the (quipment.) Over the period from the attainment of fill-scale production in 1973 until the cund of 1976. threc years latcr. the productivity of raw matcrial (chicfly ethylcne) and energy use each increased at an annual ratc of approximately 0.6 per cent. During this period average cost of production (ic. the inverse of total factor productivity) fill by three per ccont annually.

To put these improvements in perspective it is necessary to provicte standards. The two percentages quoted above start from the attainment of full-scale production. and hence are improvements upon "design costs". Few plants in developing colntries employing sophisticated techniques ever reach design standard: for the petrochemical plants in Korea to have met design standards. let alone improved upon them. is a substantial achievement. None of Dow Chemical's identical plants in other countries surpassed these achicvements. and their two plants in developing countries. Hong Kong and Chile. were inferior in terms of productivity of new materials and cnergy. and of total factor productivity.

In these terms - the surpassing of design capabilities with steady improvements in efficiency - Korea can be said to have successfully adopted petrochemical mamufaturing technology. How much of this success is a result of the policies and actions of the Korcan Government remains al vexing question. We cannot cven state that the Korean Government contributed morc to the development of its petrochemical industry

\section{Table l}

Percentage of Korean engineers among the total engaged in the adoption of two petrochemical techniques

\begin{tabular}{lccc}
\hline $\begin{array}{l}\text { stage of } \\
\text { adoption }\end{array}$ & $\begin{array}{c}\text { Percentage Korean } \\
\text { total number } \\
\text { engaged }\end{array}$ & $\begin{array}{c}\text { Ylsant plant } \\
(1970-77)\end{array}$ & 50 \\
\hline Design & 6 & 0 & 33 \\
Securing of tinance & 3 & 0 & 40 \\
Procurement & 5 & 0 & 76 \\
Construction & 25 & 72 & 67 \\
Start-up & 27 & 67 & 91 \\
Operation & 46 & 91 & \\
\hline
\end{tabular}

Source: Enos and Park. forthoming 
than did those of Hong Kong and Chile, the two less successful examples. The three countries have adopted identical techniques from the same supplier, but similarities may cease with the technology: the behaviour of the other economic agents involved the construction firms, the producing firms, the bankers - may have differed so substantially as to explain all the variation in success.

Nevertheless, we were able to identify some specific actions of the Korean Government which helped assure success. Considering the first measure of success, the organisational factor, the replacement of forcign engincers by Korcans was facilitated by the government's policies of a) concentrating university resources in the teaching of engincering (four out of every 10 graduates of Seoul National University, the nation's chief institution of higher education, are enginecrs): b) requiring the provision by the firms of housing and other social amenities for their technically skilled employees (with the desirable consequence of maintaining a core of experienced personnel); and c) negotiating with the foreign technology supplier strict terms broadening the employment and training of Koreans.

Considering the second and third measures of success, those centred upon the production of output and the utilisation of inputs, the government's chief contribution seemed to be indirect, through assuring that raw materials and other inputs were available in the amounts necessary to operate equipment at full capacity. The direct contribution of the government was to put pressure on the petrochemical manufacturers to opcrate at full capacity. Summarising, in Korea, a country whose economy was becoming increasingly integrated, the government judged performance in terms of achicvement of output targets, relying mainly upon physical and organisational controls, rather than financial controls, as the means to its end.

Even if one accepts that the Korean Government has aided the growth and improved the performance of the nation's petrochemical industry or, morcextensively. of the nation"s cconomy, one is still left ignorant of the extent of the government 's contribution. Important it may have becn, but just how important? Importance, after all, ranges from slight influence to necessity; there is nothing in out results that would permit us to locate a single point within the range. Our inclination would be to place the Korcan government's contribution toward the further, more influential extreme, but this is a subjective valuation. In the specific case of petrochemicals, we would wish to have as much information about the petrochemical industries in other countries and about their governments" roles before we made a firm judgement.

This desirc for comparative data from other developing countries is a general one. Where technology is a crucial factor, as it is in almost all modern industries, data from different countries will never be comparable unless they are generated in production processis imploying identical techniques. Only if technology is constant can the effects of differing factors such as government policy and action be evaluated. That all variables other than the one under consideration should be held constant is too demanding a prescription for rescarch in developing countries, but that the variable technology should be held constant is not too demanding, since it occurs in fact.

\section{References}

Adelman, I. and C. T. Morris, 1967. Society, Politics and Economic Development. Johns Hopkins University Press, Baltimore

Enos, J. L. and W.-H. Park, forthcoming, The Adoption and Diffusion of Imported Technology: the case of Korea. Croom Helm, London

Ho, S. P. S., 1981, 'South Korea and Taiwan: development prospects and problems in the 1980s", Asian Survey, vol 21 no 12 , December

Jones, L. and 1. Sakong, 1980. Government Business and Entrepreneurship in Economic Development: the Korean case, Harvard University Press, Cambridge (Mass)

Wade, R., 1982, Irrigation and Agricultural Politics in South Korea, Westview Press, Boulder (Co) 